\title{
Positive association between COVID-19 deaths and influenza vaccination rates in elderly people worldwide
}

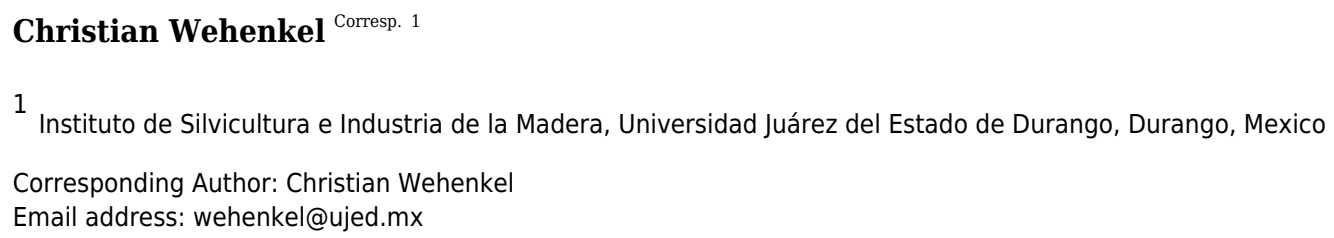

Background. The coronavirus disease 2019 (COVID-19) pandemic, caused by severe acute respiratory syndrome coronavirus 2 (SARS-CoV-2), is an ongoing global health crisis, directly and indirectly impacting all spheres of human life. Some pharmacological measures have been proposed to prevent COVID-19 or reduce its severity, such as vaccinations. Previous reports indicate that influenza vaccination appears to be negatively correlated with COVID-19-associated mortality, perhaps as a result of heterologous immunity or changes in innate immunity. The understanding of such trends in correlations could prevent deaths from COVID-19 in the future. The aim of this study was therefore to analyze the association between COVID-19 related deaths and influenza vaccination rate (IVR) in elderly people worldwide. Methods. To determine the association between COVID-19 deaths and influenza vaccination, available data sets from countries with more than 0.5 million inhabitants were analyzed (in total 39 countries).To accurately estimate the influence of IVR on COVID-19 deaths and mitigate effects of confounding variables, a sophisticated ranking of the importance of different variables was performed, including as predictor variables IVR and some potentially important geographical and socioeconomic variables as well as variables related to non-pharmaceutical intervention. The associations were measured by non-parametric Spearman rank correlation coefficients and random forest functions. Results. The results showed a positive association between COVID-19 deaths and IVR of people $\geq 65$ years-old. Further exploration is needed to explain these findings, and additional work on this line of research may lead to prevention of deaths associated with COVID-19. 


\section{Positive association between COVID-19 deaths and influenza vaccination rates in elderly people worldwide}

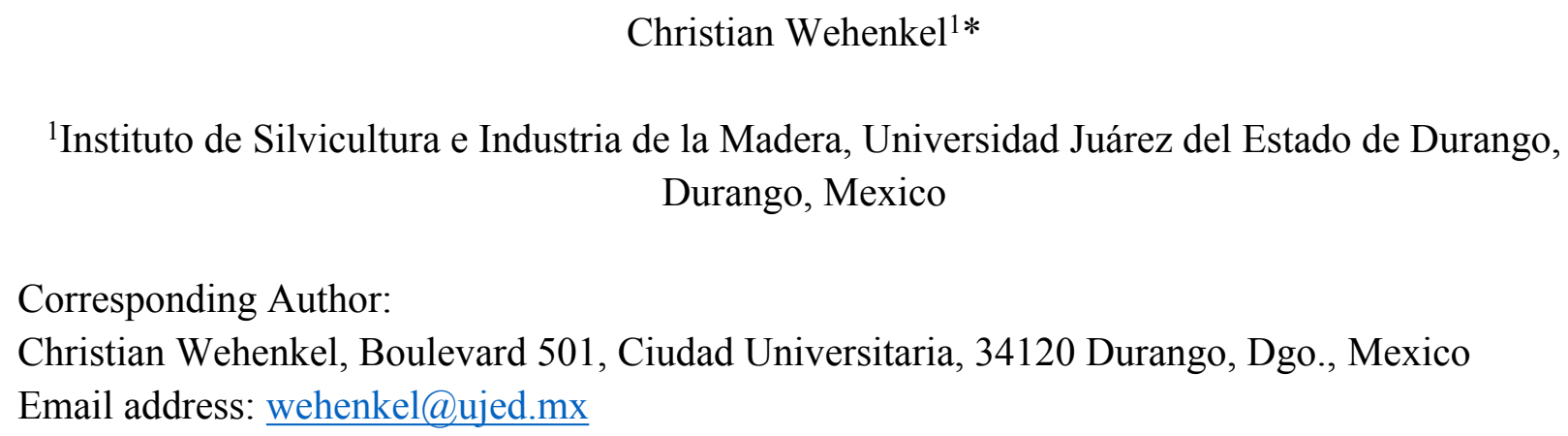

\section{Abstract}

Background. The coronavirus disease 2019 (COVID-19) pandemic, caused by severe acute respiratory syndrome coronavirus 2 (SARS-CoV-2), is an ongoing global health crisis, directly and indirectly impacting all spheres of human life. Some pharmacological measures have been proposed to prevent COVID-19 or reduce its severity, such as vaccinations. Previous reports indicate that influenza vaccination appears to be negatively correlated with COVID-19associated mortality, perhaps as a result of heterologous immunity or changes in innate immunity. The understanding of such trends in correlations could prevent deaths from COVID19 in the future. The aim of this study was therefore to analyze the association between COVID19 related deaths and influenza vaccination rate (IVR) in elderly people worldwide.

Methods. To determine the association between COVID-19 deaths and influenza vaccination, available data sets from countries with more than 0.5 million inhabitants were analyzed (in total 39 countries).To accurately estimate the influence of IVR on COVID-19 deaths and mitigate effects of confounding variables, a sophisticated ranking of the importance of different variables was performed, including as predictor variables IVR and some potentially important geographical and socioeconomic variables as well as variables related to non-pharmaceutical intervention. The associations were measured by non-parametric Spearman rank correlation coefficients and random forest functions.

Results. The results showed a positive association between COVID-19 deaths and IVR of people $\geq 65$ years-old. Further exploration is needed to explain these findings, and additional work on this line of research may lead to prevention of deaths associated with COVID-19. 
35

36

37

38

39

40

41

42

43

44

45

46

47

48

49

50

51

52

53

54

55

56

57

58

59

60

61

62

63

64

\section{Introduction}

The coronavirus disease 2019 (COVID-19) pandemic, caused by severe acute respiratory syndrome coronavirus 2 (SARS-CoV-2), is an ongoing global health crisis (Yuen et al. 2020), directly and indirectly impacting all spheres of human life (Ozili \& Arun 2020). More than 15,300,000 confirmed cases including more than 630,000 deaths have been documented worldwide, affecting 213 countries and territories around the world (https://covid19.who.int/).

Determining the factors influencing the severity of COVID-19 is important (Armengaud et al. 2020). Although COVID-19 disease does not only affect elderly people, the severity of symptoms increases with age (https:/www.cdc.gov/coronavirus/2019-ncov/need-extraprecautions/older-adults.html; Le Couteur, Anderson \& Newman 2020). Several other risk factors have been found for severe COVID-19, such as comorbidities, dyspnea, chest pain, cough, expectoration, decreased lymphocytes, and increased inflammation indicators (Li et al. 2020). Low socioeconomic status is an additional risk factor (Yancy 2020).

In response to the increasing numbers of COVID-19 cases and deaths, numerous nonpharmaceutical interventions have been implemented, including social distancing, border closures, school closures, measures to isolate symptomatic individuals and their contacts, and large-scale lockdowns of populations (Courtemanche et al. 2020; Flaxman et al. 2020). Some pharmacological measures have also (often controversially) been proposed in order to prevent COVID-19 disease or reduce its severity, such as the use of remdesivir (e.g., Beigel et al. 2020), dexamethasone (RECOVERY Collaborative Group 2020), adjunctive therapies (https://files.covid19treatmentguidelines.nih.gov/guidelines/section/section_85.pdf) and COVID19 candidate vaccines (e.g., Graham 2020, https://www.who.int/publications/m/item/draftlandscape-of-covid-19-candidate-vaccines.

The term "heterologous immunity" is applied when an infection by one pathogen can induce and/or alter the immune response against another unrelated pathogen. Heterologous immunity can improve or decrease protective immunity against a given pathogen, and/or cause severe immunopathology or tolerance to self-antigens. Heterologous immunity can also result in nonspecific effects (also called "heterologous effects") of vaccines which affect unrelated infections and diseases, such as extending the protective outcomes of vaccinations (Goodridge et al. 2016, 
65

66

67

68

69

70

71

72

73

74

75

76

77

78

79

80

81

82

83

84

85

86

87

88

89

90

91

92

93

94

Agrawal 2019). Arokiaraj (2020) reported a negative correlation between influenza vaccination rates and COVID-19 related mortality and morbidity. Marín-Hernández et al. (2020) also showed epidemiological evidence of an association between higher influenza vaccine uptake by elderly people and lower percentage of COVID-19 deaths in Italy. In a study analyzing 92,664 clinically and molecularly confirmed COVID-19 cases in Brazil, Fink et al. (2020) reported that patients who received a recent flu vaccine experienced on average $17 \%$ lower odds of death. Moreover, Pawlowski et al. (2020) analyzed the immunization records of 137,037 individuals who tested positive in a SARS-CoV-2 PCR. They found that polio, Hemophilus influenzae type-B (HIB), measles-mumps-rubella (MMR), varicella, pneumococcal conjugate (PCV13), geriatric flu, and hepatitis A / hepatitis B (HepA-HepB) vaccines, which had been administered in the past one, two, and five years, were associated with decreased SARS-CoV-2 infection rates.

By contrast, in a study with 6,120 subjects, Wolff (2020) reported that influenza vaccination was significantly associated with a higher risk of some other respiratory diseases, due to virus interference. In a specific examination of non-influenza viruses, the odds of coronavirus infection (but not the COVID-19 virus) in vaccinated individuals were significantly higher, when compared to unvaccinated individuals (odds ratio $=1.36)$.

Given that heterologous immunity could improve protective immunity against COVID-19 and, thus, prevent COVID-19 deaths in the future, the aim in this study was to analyze the possible association between COVID-19 deaths and the influenza vaccination rate in elderly people worldwide, with a negative association expected.

\section{Materials \& Methods}

To look for an association between COVID-19 deaths and influenza vaccination, I analyzed available data sets from 39 countries, each with $\geq 0.5$ million inhabitants. In smaller states (i.e., $<$ 0.5 million inhabitants), the rate of erroneous identification of COVID-19 deaths may be particularly high due to the lack of expertise, measuring devices and experience. Moreover, in such microstates small absolute changes in COVID-19 deaths may result in extreme values of relative indices, such as COVID-19 deaths per million inhabitants (DPMI) and COVID-19 Case Fatality Ratio (CFR). I analyzed the variables DPMI and CFR, based on documented COVID-19 cases per million inhabitants (CPMI) in 2020, COVID-19 tests per million inhabitants, and 
95 influenza vaccination rate (IVR) (\%) in people $\geq 65$ years old in 2019 or latest available data

96 (Table 1). I recorded the DPMI, CPMI and CFR data from the public web site

97 https://www.worldometers.info/coronavirus/. Then, I calculated CFR as the rate of DPMI per

98 CPMI. IVR data were also taken from https://data.oecd.org/healthcare/influenza-vaccination-

99 rates.htm, https://oecdcode.org/disclaimers/israel.html and

100 https://www.statista.com/chart/16575/global-flu-immunization-rates-vary/(retrieved on July 25,

101 2020). Vietnam's 2017 IVR was recorded from Nguyen et al. (2020), and Singapore's 2016/2017

102 IVR from https://www.todayonline.com/commentary/why-singapores-adult-vaccination-rate-so-

103 low.

104 To analyze the data, I first calculated the non-parametric Spearman rank correlation coefficient

$105\left(r_{S}\right)$ and its $R_{S}{ }^{2}$ and respective $p$-value (2-tailed) to determine any association between DPMI and

106 CFR with IVR, using $R$ (R Core Team 2017). As the relationship between DPMI and the number

107 of people tested for COVID-19 was not statistically significant based on $r_{s}$ and its $p$-value, I did

108 not modified (corrected) the DPMI data set. Then, I created regression curves by Generalized

109 additive model (GAM) using the "ggplot2" package and function (method = 'gam') (Wickham et

110 al. 2013), also in $R$.

111 As the analysis included countries with different socioeconomic status, demographic structure,

$112 \mathrm{urban} /$ rural settings, time of arrival of the pandemic and national control strategies, there may be

113 complex interactions between IVR and other correlated predictor variables. With the aim of

114 accurately estimating the influence of IVR on DPMI and CFR and mitigating the effects of

115 confounding variables, I performed variable importance ranking, including as predictor variables

116 IVR and some potentially important geographical, socioeconomic and non-pharmaceutical-

117 intervention variables (Escobar et al. 2020). I used the centroid longitudes $\left({ }^{\circ}\right)$ and latitudes $\left(^{\circ}\right)$ of

118 each country as geographical variables calculated by the "rgeos" and "rworldmap" packages,

119 along with the "getMap" and "gCentroid" functions, implemented in $R$ (version 3.3.4; $\mathrm{R}$

120 Development Core Team, 2017). For each country considered, the study recorded socioeconomic

121 variables as the degree of urbanization (DUR) in 2020

122 (https://www.cia.gov/library/publications/the-world-factbook/fields/349.html), the population

123 density (PD) in 2018 (https://data.worldbank.org/indicator/EN.POP.DNST), the Human

124 Development Index (HDI) in 2018 (http://hdr.undp.org/en/composite/HDI) and the percentage of 125 elderly people (PEP) in 2019 
126 (https://data.worldbank.org/indicator/SP.POP.65UP.TO.ZS?name desc=false), which were all

127 retrieved on July 13, 2020 (Table 2). Finally, I recorded two aspects as Covid-19 prevention

128 measures, i.e. the degree of requirement to use masks (mask) in public (with three degrees: none,

129 parts of country, full country) (https://masks4all.co/what-countries-require-masks-in-public/) and

130 the lockdown degree (lockdown) (with three levels: no lockdown, partial lockdown, nationwide

131 lockdown); all of these sources and the noted in Table 3 were consulted on Aug 13, 2020.

132

133 Variable importance ranking was carried out using the "party" package and the non-parametric

134 random forest function "cforest", along with Out of bag (OOB) score (with the default option

135 "controls = cforest_unbiased" and the conditional permutation importance "varimp(obj,

136 conditional = TRUE)"). Following the permutation principle of the "mean decrease in accuracy"

137 importance, this machine learning algorithm guarantees unbiased variable importance for

138 predictor variables of different types (Strobl et al. 2008).

139

140 To mitigate the effects of confounding factors, IVR, DPMI and CFR evaluations were also

141 conducted for countries with similar social conditions ( $>50 \%$ of DUR, HDI of $>0.80,>15 \%$ of

142 PEP, and PD between 25 and 350 inhabitants per $\mathrm{km}^{2}$ ) (Escobar et al. 2020) and for countries

143 with similar longitudes $\left(10-20^{\circ}\right.$ in parts of Europe and $100-140^{\circ}$, East and Southeast Asia

144 along with Australia and New Zealand).

145 As IVR and the other eight predictor variables were not strongly correlated $\left(\left|r_{s}\right| \leq 0.57 ; r_{s}\right.$ (IVR x

146 DUR $)=+0.52 ; r_{s}($ IVR $\times$ Long $)=-0.46 ; r_{s}($ IVR $\times$ HDI $\left.)=0.36\right)$, therefore, I included these

147 variables in non-parametric Random Forest (RF) models of DPMI and CFR, including a 5-fold

148 cross validation approach, repeated 30 times using the package "caret" together with the function

149 "train” (Venables and Ripley, 1999; Williams et al., 2018,

150 http://topepo.github.io/caret/index.html) in $R$ software. Finally, I evaluated the goodness-of-fit of

151 the regression model using the (pseudo) coefficient of determination $\left(R^{2}\right)$ and the root mean

152 square error (RMSE).

153

154 Results

155 For the 26 European countries considered, the results indicated that COVID-19 deaths per

156 million inhabitants (DPMI) and the COVID-19 Case Fatality Ratio (CFR) were positively and 
157 statistically significantly associated with influenza vaccination rate (IVR) in people $\geq 65$ years158 old in 2019 or latest data available $\left(r_{s}(\right.$ IVR x DPMI $)=+0.62$ with $p=0.0008, R_{s}{ }^{2}(\mathrm{IVR} \times \mathrm{DPMI})$ $159=0.38 ; r_{s}($ IVR $\times$ CFR $)=+0.50$ with $p=0.01, R_{S}^{2}($ IVR $\times$ CFR $\left.)=0.25\right)($ Figs. 1 and 2, Table 4).

160 In evaluations including only countries with similar social conditions, $r_{s}$ (IVR x DPMI) was 161 equal to $+0.65(p=0.002, \mathrm{~N}=20)$ and $r_{s}(\mathrm{IVR} \times \mathrm{CFR})+0.48(p=0.03, \mathrm{~N}=20)$. In analyses 162 including only countries with similar longitude of the country centroid (Long), $r_{s}$ (IVR x DPMI) 163 was equal to $+0.83(p=0.003, \mathrm{~N}=10)$ (Long from 10 to $\left.20^{\circ}\right)$ and $r_{s}(\mathrm{IVR} \times \mathrm{DPMI})+0.76(p=$ $1640.046, \mathrm{~N}=7$ ) (Long from 100 to $140^{\circ}$ ).

165 At worldwide level (39 countries studied), the positive associations between DPMI and IVR 166 were also statistically significant $\left(r_{s}(\mathrm{IVR} \times \mathrm{DPMI})=+0.49\right.$ with $p=0.0016, R_{s}{ }^{2}(\mathrm{IVR} \times \mathrm{DPMI})=$ 167 168

169

170

171

172

173

174

175

176

177

178

179

180

181

182

183

184 185

186

187

188

0.24) (Fig. 3, Table 5). However, the relationships between IVR and CFR were not statistically significant.

In the IVR interval from 7 to $50 \%$, the association was not significant, although a trend for DPMI and CFR to be positively associated with IVR was observed. DPMI and CFR varied strongly when IVR was 50\% or higher (Figs. 1-3).

Worldwide, the unbiased ranking showed the degree of importance of each variable analyzed.

The variables Long (with 55.9 and $52.3 \%$ ) and IVR (with 36.3 and $24.5 \%$ ) were by far the most important of the nine variables used to predict DPMI and CFR, respectively. The degree of urbanization (DUR) in 2020 was the third most important variable, with an importance of 5.7\% for predicting DPMI. The percentage of elderly people (PEP) in 2019 was the third most important variable (11.5\%) in the CFR model (Figs. 4 and 5). The nine predictor variables considered in this study explained $63 \%$ of the variation in DPMI (RMSE $=161.9)$ and $43 \%$ of the variation in CFR $(\mathrm{RMSE}=0.039)$.

\section{Discussion}

Contrary to expectations, the present worldwide analysis and European sub-analysis do not support the previously reported negative association between COVID-19 deaths (DPMI) and influenza vaccination rate (IVR) in elderly people, observed in studies in Brazil and Italy (Fink et al. 2020; Marín-Hernández et al. 2020). Previous studies attributed the beneficial effect of influenza vaccination in reducing severity of COVID-19 disease to better prevention of potential influenza-SARS-CoV-2 coinfections (Arokiaraj 2020) and, more likely, to changes in innate 
189 immunity (Netea et al. 2020). The innate immune response induced by recent vaccination could 190 result in more rapid and efficient SARS-CoV-2 clearance, preventing progressive dissemination 191 into lower areas of lung tissues (Fink et al. 2020).

192 The negative association between the proportion of DPMI and IVR found in Italy was explained 193 as probably caused by i) a higher influenza vaccine rate occurring in higher economic groups 194 with overall better health, ii) chance, iii) a relationship with seasonal respiratory virus infections, 195 or iv) an unrelated mechanistic association (Marín-Hernández et al. 2020). However, the 196 induction of cross-neutralizing antibodies and T-cells that directly target other RNA viruses like 197 SARS-CoV-2 and cross-protection seem unlikely, given the extraordinary diversity of influenza 198 viruses (Fink et al. 2020).

199 Therefore, the above-mentioned arguments cannot explain the positive, direct or indirect 200 relationship between IVR and both DPMI and CFR found in this study, which was confirmed by 201 an unbiased ranking variable importance (Figs. 4 and 5) using RF models. The influenza vaccine 202 may increase influenza immunity at the expense of reduced immunity to SARS-CoV-2 by some 203 unknown biological mechanism, as suggested by Cowling et al. (2012) for non-influenza 204 respiratory virus. Alternatively, weaker temporary, non-specific immunity after influenza viral 205 infection could cause this positive association due to stimulation of the innate immune response 206 during and for a short time after infection (McGill et al. 2009; Khaitov et al. 2009). People who 207 had received the influenza vaccination would have been protected against influenza but not 208 against other viral infections, due to reduced non-specific immunity in the following weeks 209 (Cowling et al. 2012), probably caused by virus interference (Isaacs \& Lindenmann 1957; 210 Seppälä et al. 2011; Wolff 2020). Although existing human vaccine adjuvants have a high level 211 of safety, specific adjuvants in influenza vaccines should also be tested for adverse reactions, 212 such as additionally increased inflammation indicators (Petrovsky 2015) in Covid-19 patients 213 with already strongly increased inflammation (Qin et al. 2020).

214 The strong variation in DPMI and CFR from an IVR of about 50\% or larger may be the result of 215 interactions among the different measures applied in the analyzed countries (Figs. 1-3), e.g. 216 initiation of interventions, emergency plans and health systems against COVID-19. For example, 217 Australia and South Korea had a very low DPMI and CFR compared with Belgium and United 218 Kingdom (Table 1). 
219 The high correlation between the longitude of the country centroid and DPMI and CFR 220 emphasize a significant increase in CP and CFR from eastern to western regions in the world 221 (Table 5, Figs. 4 and 5), as confirmed by Leung et al. (2020) and Skórka et al. (2020). Longitude 222 could act as a proxy for variables such as lifestyle, social behavior, genetics, geographically 223 isolated and remote populations, which may also be associated with CP and CFR. In the severe 224 1918-1919 influenza pandemic, remote or isolated populations were also affected, at least partly 225 because of the lack of prior immunity in locations that had not been recently affected by any 226 form of influenza (Mathews et al. 2009). Therefore, crossing geographical and ecological 227 barriers also is a key factor in spreading diseases (Hallatschek \& Fisher 2014; Murray et al. 228 2015).

229 Both DPMI and CFR were weakly and positively correlated $(\mathrm{p}<0.05)$ with the absolute value of 230 geographical latitude (abs(Lat)), degree of urbanization (DUR), percentage of elderly people 231 (PEP) and population density (Tables 4 and 5). In a global analysis, Escobar et al. (2020) also 232 found positive associations between COVID-19 mortality and the percentage of population aged $233 \geq 65$ years and urbanization, but still more strongly with the Human Development Index. Leung 234 et al. (2020) also reported positive associations between latitude, temperature by week and by 235 month prior to the first reported COVID-19 case. Lower temperature at northern latitudes was a 236 strong independent predictor of national COVID-19 mortality.

237 Although countywide lockdowns and use of face masks by the general public should reduce 238 COVID-19 transmission (Conyon, He \& Thomsen 2020; Eikenberry et al. 2020), the variables 239 lockdown degree and the degree of requirement for mask use in public were not associated with 240 DPMI and CFR in the present study (Tables 4 and 5, Figs 4 and 5). Leffler et al. (2020) reported 241 in a global study that internal lockdown requirements were not associated with mortality, but that 242 in countries that recommended use of face masks early on at the national level, the COVID-19 243 death rate was lower than expected.

244 Although countywide lockdowns were proclaimed in many countries, the restrictive measures 245 and their implementations differed in degree, strictness and implementation date in relation to the 246 advance of the disease (see references in Table 3). Also, although many countries have required 247 masks in public, the mask quality and correct use may differ from country to country. In this 248 regard, Fischer et al. (2020) found that the use of ineffective masks could be counterproductive. 
249 This could explain the non-significant differences between the means of DPMI among countries 250 with and without one or both requirements, lockdown and masks.

251 Finally, the study is limited by the fact that I didn't normalize the time of arrival of the 252 pandemic. Moreover, the associations found may change in the future because the COVID-19 253 pandemic was not over at the end of the study.

\section{Conclusions}

255

256

Given the positive relationship between influenza vaccination rate and the number of deaths per

257 million found in this study, further exploration would be valuable to explain these findings and to make conclusions. Additional work on this line of research may also yield results to improve 259 prevention of COVID-19 deaths.

\section{Acknowledgements}

261

262 I am grateful to María del Socorro González-Elizondo and José Ciro Hernández-Díaz for their comments on the manuscript, and to Dr. Daniela Marín-Hernández and an anonymous reviewer for their careful review and insightful comments.

265

266

\section{References}

267

268

Agrawal B. 2019. Heterologous immunity: Role in natural and vaccine-induced resistance to 269 infections. Frontiers in Immunology 10.

270 Armengaud J, Delaunay-Moisan A, Thuret JY, Van Anken E, Acosta-Alvear D, Aragón T, ... ,

271 Courcol R. 2020. The importance of naturally attenuated SARS-Cov-2 in the fight against

272 Covid-19. Environmental Microbiology 22(6): 1997-2000.

273 Arokiaraj MC. 2020. Correlation of Influenza Vaccination and the COVID-19 Severity.

274 Available at SSRN https://ssrn.com/abstract=3572814 or http://dx.doi.org/10.2139/ssrn.3572814

275 Beigel JH, Tomashek KM, Dodd LE, Mehta AK, Zingman BS, Kalil AC, Hohmann E, Chu HY, 276 Luetkemeyer A, Kline S, Lopez de Castilla D. 2020. Remdesivir for the treatment of Covid-19 277 preliminary report. New England Journal of Medicine.

278 Conyon MJ, He L, Thomsen S. 2020. Lockdowns and COVID-19 deaths in Scandinavia. 279 Available at SSRN 3616969. 
280 Courtemanche C, Garuccio J, Le A, Pinkston J, Yelowitz A. 2020. Strong Social Distancing 281 Measures in the United States Reduced The COVID-19 Growth Rate: Study evaluates the impact 282 of social distancing measures on the growth rate of confirmed COVID-19 cases across the 283 United States. Health Affairs 10: 1377.

284 Cowling BJ, Fang VJ, Nishiura H, Chan KH, Ng S, Ip DK, ... , Peiris JM. 2012. Increased risk of 285 noninfluenza respiratory virus infections associated with receipt of inactivated influenza vaccine. 286 Clinical Infectious Diseases 54(12): 1778-1783.

287 Eikenberry SE, Mancuso M, Iboi E, Phan T, Eikenberry K, Kuang Y, ... Gumel AB. 2020. To 288 mask or not to mask: Modeling the potential for face mask use by the general public to curtail the 289 COVID-19 pandemic. Infectious Disease Modelling.

290 Escobar LE, Molina-Cruz A, Barillas-Mury C. 2020. BCG vaccine protection from severe 291 coronavirus disease 2019 (COVID-19). Proc Natl Acad Sci USA 117(30):17720-17726. 292 doi:10.1073/pnas.2008410117

293 Fink G, Orlova-Fink N, Schindler T, Grisi S, Ferrer AP, Daubenberger C, Brentani A. 2020.

294 Inactivated trivalent influenza vaccine is associated with lower mortality among Covid-19 295 patients in Brazil. medRxi.

296 Fischer EP, Fischer MC, Grass D, Henrion I, Warren WS, Westman E. 2020. Low-cost 297 measurement of facemask efficacy for filtering expelled droplets during speech. Science 298 Advances, eabd3083.

299 Flaxman S, Mishra S, Gandy A, Unwin HJT, Mellan TA, Coupland H, ... Monod M. 2020.

300 Estimating the effects of non-pharmaceutical interventions on COVID-19 in Europe. Nature:1-5.

301 Goodridge HS, Ahmed SS, Curtis N, Kollmann TR, Levy O, Netea MG, ... Wilson CB. 2016.

302 Harnessing the beneficial heterologous effects of vaccination. Nature Reviews Immunology 303 16(6): 392-400.

304 Graham BS 2020. Rapid COVID-19 vaccine development. Science 368(6494): 945-946.

305 Hallatschek O, Fisher DS. 2014. Acceleration of evolutionary spread by long-range dispersal. 306 PNAS 111: E4911-E4919.

307 Isaacs A., Lindenmann J. 1957. Virus interference. I. The interferon. Proceedings of the Royal 308 Society of London. Series B-Biological Sciences 147(927): 258-267. 
309 Khaitov M, Laza-Stanca V, Edwards MR, Walton RP, Rohde G, Contoli M., ..., Johnston SL.

310 2009. Respiratory virus induction of alpha-, beta-and lambda-interferons in bronchial epithelial

311 cells and peripheral blood mononuclear cells. Allergy 64(3): 375-386.

312 Le Couteur DG, Anderson RM, Newman AB. 2020. COVID-19 is a disease of older people. $J$

313 Gerontol A Biol Sci Med Sci 10.

314 Leffler CT, Ing EB, Lykins JD, Hogan MC, McKeown CA, Grzybowski A. 2020. Association of

315 country-wide coronavirus mortality with demographics, testing, lockdowns, and public wearing

316 of masks. Update June 2, 2020. medRxiv.

317 Leung NY, Bulterys MA, Bulterys PL. 2020. Predictors of COVID-19 incidence, mortality, and

318 epidemic growth rate at the country level. medRxiv.

319 Li K, Wu J, Wu F, Guo D, Chen L, Fang Z, Li C. 2020. The clinical and chest CT features

320 associated with severe and critical COVID-19 pneumonia. Investigative Radiology.

321 Marín-Hernández D, Schwartz RE, Nixon DF. 2020. Epidemiological Evidence for Association

322 between Higher Influenza Vaccine Uptake in the Elderly and Lower COVID-19 Deaths in Italy.

323 Journal of Medical Virology.

324 Mathews JD, Chesson JM, McCaw JM, McVernon J. 2009. Understanding influenza

325 transmission, immunity and pandemic threats. Influenza and other respiratory viruses 3(4): 143326149.

327 McGill J, Heusel JW, Legge KL. 2009. Innate immune control and regulation of influenza virus 328 infections. Journal of Leukocyte Biology 86(4): 803-812.

329 Murray KA, Preston N, Allen T, Zambrana-Torrelio C, Hosseini PR, Daszak P. 2015. Global

330 biogeography of human infectious diseases. Proceedings of the National Academy of Sciences

331 112(41): 12746-12751.

332 Netea MG, Domínguez-Andrés J, Barreiro LB, Chavakis T, Divangahi M, Fuchs E., ..., Riksen

333 NP. 2020. Defining trained immunity and its role in health and disease. Nature Reviews

334 Immunology 1-1

335 Nguyen TTM., Lafond KE, Nguyen TX, Tran PD, Nguyen HM, Do TT, ..., McFarland JW.

336 2020. Acceptability of seasonal influenza vaccines among health care workers in Vietnam in

337 2017. Vaccine 38(8): 2045-2050.

338 Petrovsky N. 2015. Comparative safety of vaccine adjuvants: a summary of current evidence and 339 future needs. Drug safety 38(11): 1059-1074. 
340 Ozili PK, Arun T. 2020. Spillover of COVID-19: impact on the Global Economy. Available at 341 SSRN 3562570.

342 Pawlowski C, Puranik A, Bandi H, Venkatakrishnan AJ, Agarwal V, Kennedy R, ... Badley AD. 343 2020. Exploratory analysis of immunization records highlights decreased SARS-CoV-2 rates in 344 individuals with recent non-COVID-19 vaccinations. medRxiv.

345 Qin C, Zhou L, Hu Z, Zhang S, Yang S, Tao Y, ... Tian DS. 2020. Dysregulation of immune 346 response in patients with COVID-19 in Wuhan, China. Clinical Infectious Diseases.

347 R Core Team. 2017. R: A language and environment for statistical computing. R Foundation for 348 Statistical Computing, Vienna, Austria. URL http://www.R-project.org.

349 RECOVERY Collaborative Group, 2020. Dexamethasone in hospitalized patients with Covid350 19-preliminary report. New England Journal of Medicine.

351 Seppälä E, Viskari H, Hoppu S, Honkanen H, Huhtala H, Simell O, ..., Hyöty H. (2011). Viral 352 interference induced by live attenuated virus vaccine (OPV) can prevent otitis media. Vaccine 353 29(47): 8615-8618.

354 Skórka P, Grzywacz B, Moroń D, Lenda M. 2020. The macroecology of the COVID-19 355 pandemic in the Anthropocene. Plos one 15(7): e0236856.

356 Strobl C, Boulesteix AL, Kneib T, Augustin T, Achim Zeileis A. 2008. Conditional Variable 357 Importance for Random Forests. BMC Bioinformatics 9: 307.

358 http://www.biomedcentral.com/1471-2105/9/307

359 Venables WN, Ripley BD. 1999. Chapter 10: Tree-based methods. In Modern Applied Statistics 360 with S-PLUS. 3rd ed. Eds. J. Chambers, W. Eddy, W. Härdle, S. Sheather, L. Tierney. Statistics 361 and Computing (Springer-Verlag, Press), New York, NY, 303-327. doi: 10.1007/978-1-4757362 3121-7_10

363 Wickham H, Chang W, Wickham MH. 2013. Package 'ggplot2'. Computer software manual.

364 Retrieved from http://cran.r-project.org/web/packages/ggplot2/ggplot2.pdf (R package version 365 0.9. 3.1) Google Scholar.

366 Williams CK, Engelhardt A, Cooper T, Mayer Z, Ziem A, Scrucca L, Kuhn MM. 2018. Package 367 'caret'.

368 Wolff GG. 2020. Influenza vaccination and respiratory virus interference among Department of 369 Defense personnel during the 2017-2018 influenza season. Vaccine 38(2): 350-354.

370 Yancy CW. 2020. COVID-19 and African Americans. Jama. 
371 Yuen KS, Ye ZW, Fung SY, Chan CP, Jin DY. 2020. SARS-CoV-2 and COVID-19: The most 372 important research questions. Cell \& bioscience 10(1): 1-5.

373 Venables WN, Ripley BD. 1999. Chapter 10: Tree-based methods. In Modern Applied Statistics 374 with S-PLUS. 3rd ed. Eds. J. Chambers, W. Eddy, W. Härdle, S. Sheather, L. Tierney. Statistics 375 and Computing (Springer-Verlag, Press), New York, NY, 303-327. doi: 10.1007/978-1-4757376 3121-7_10 


\section{Figure 1}

Association of COVID-19 deaths per million inhabitants (DPMI) up to July 25, 2020 with influenza vaccination rate (IVR) of people aged 65 and older in 2019 or latest data available in Europe.

Association of COVID-19 deaths per million inhabitants (DPMI) up to July 25, 2020 with influenza vaccination rate (IVR) of people aged 65 and older in 2019 or latest data available in Europe (26 countries with more than 0.5 million inhabitants). The mean (blue line) and standard deviation (grey area) are based on generalized additive models (GAM); $r_{s}$ (IVR $\times$ DP) $=+0.687$ with $p=0.00015$. 


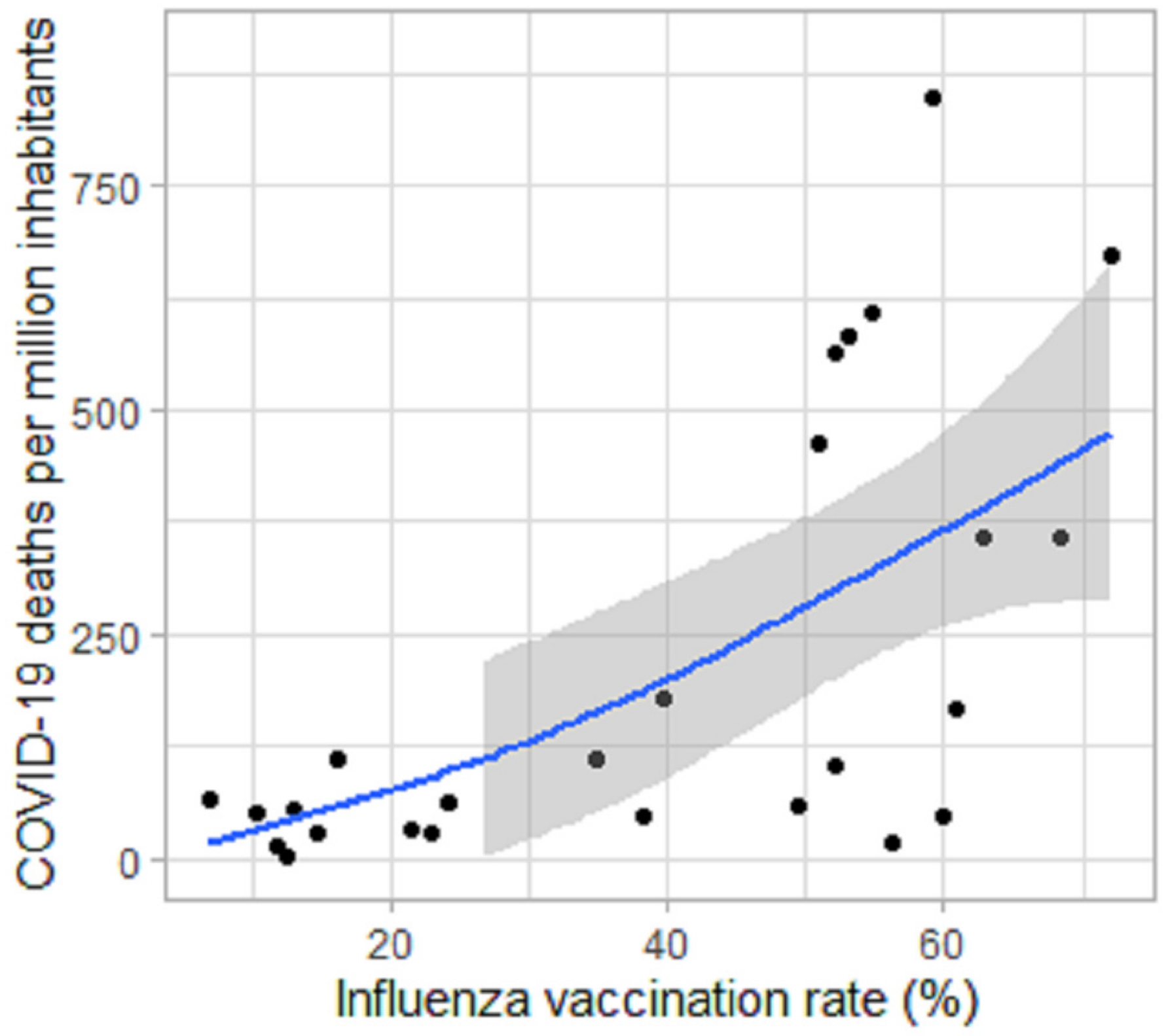




\section{Figure 2}

Association of COVID-19 Case Fatality Ratio (CFR) up to July 25, 2020 with influenza vaccination rate (IVR) of people aged 65 and older in 2019 or latest data available in Europe.

Association of COVID-19 Case Fatality Ratio (CFR) up to July 25, 2020 with influenza vaccination rate (IVR) of people aged 65 and older in 2019 or latest data available in Europe ( 26 countries with more than 0.5 million inhabitants). The mean (blue line) and standard deviation (grey area) are based on generalized additive models (GAM); $r_{s}($ IVR $\times$ CFR) $=$ +0.629 with $p=0.00075$. 


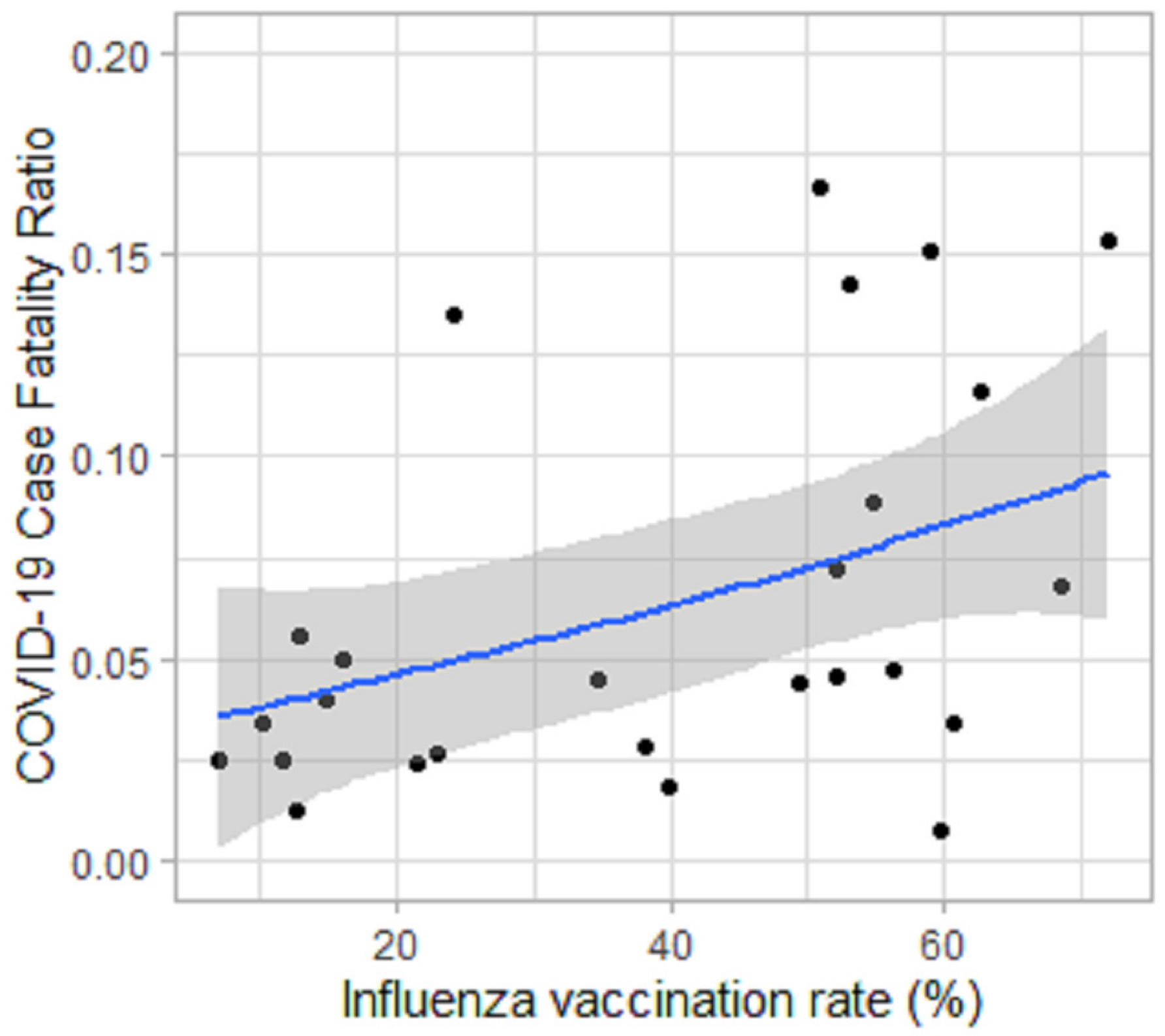




\section{Figure 3}

Association of COVID-19 deaths per million inhabitants (DPMI) up to July 25, 2020 with influenza vaccination rate of people aged 65 and older in 2019 or latest data available worldwide.

Association of COVID-19 deaths per million inhabitants (DPMI) up to July 25, 2020 with influenza vaccination rate of people aged 65 and older in 2019 or latest data available worldwide (39 countries with more than 0.5 million inhabitants). The mean (blue line) and standard deviation (grey area) are based on generalized additive models (GAM); $r_{s}$ (IVR $\times$ DP) $=+0.487$ with $p=0.0017$. 


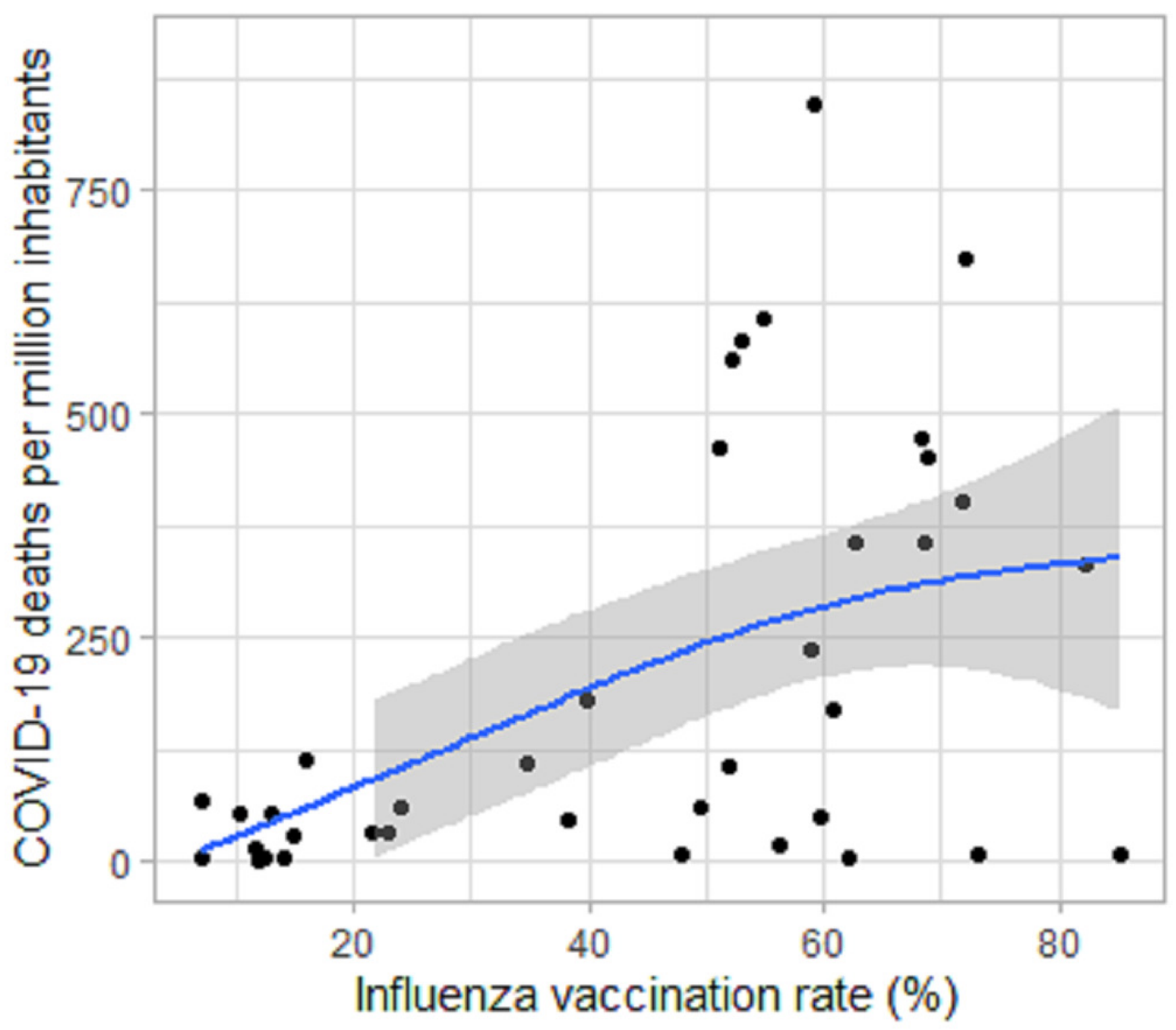




\section{Figure 4}

Unbiased Conditional variables importance ranking to predict COVID-19 deaths per million inhabitant.

Unbiased conditional variables importance ranking (\%) to predict COVID-19 deaths per million inhabitants using the package "party" and the non-parametric random forest function "cforest" in the software $R$; IVR = influenza vaccination rate, Long = centroid longitude $\left({ }^{\circ}\right.$ ), Lat $=$ centroid latitude $\left(^{\circ}\right)$, DUR $=$ degree of urbanization in $2020, \mathrm{HDI}=$ Human Development Index in 2018, PEP = percent of elder people in 2019, PD = population density in 2018, mask = the requirement degree of using masks in public (with three degrees: none, parts of country, full country), lockdown = lockdown degree (with three levels: no lockdown, partial lockdown, nationwide lockdown) of each country, at worldwide level (39 countries studied). 


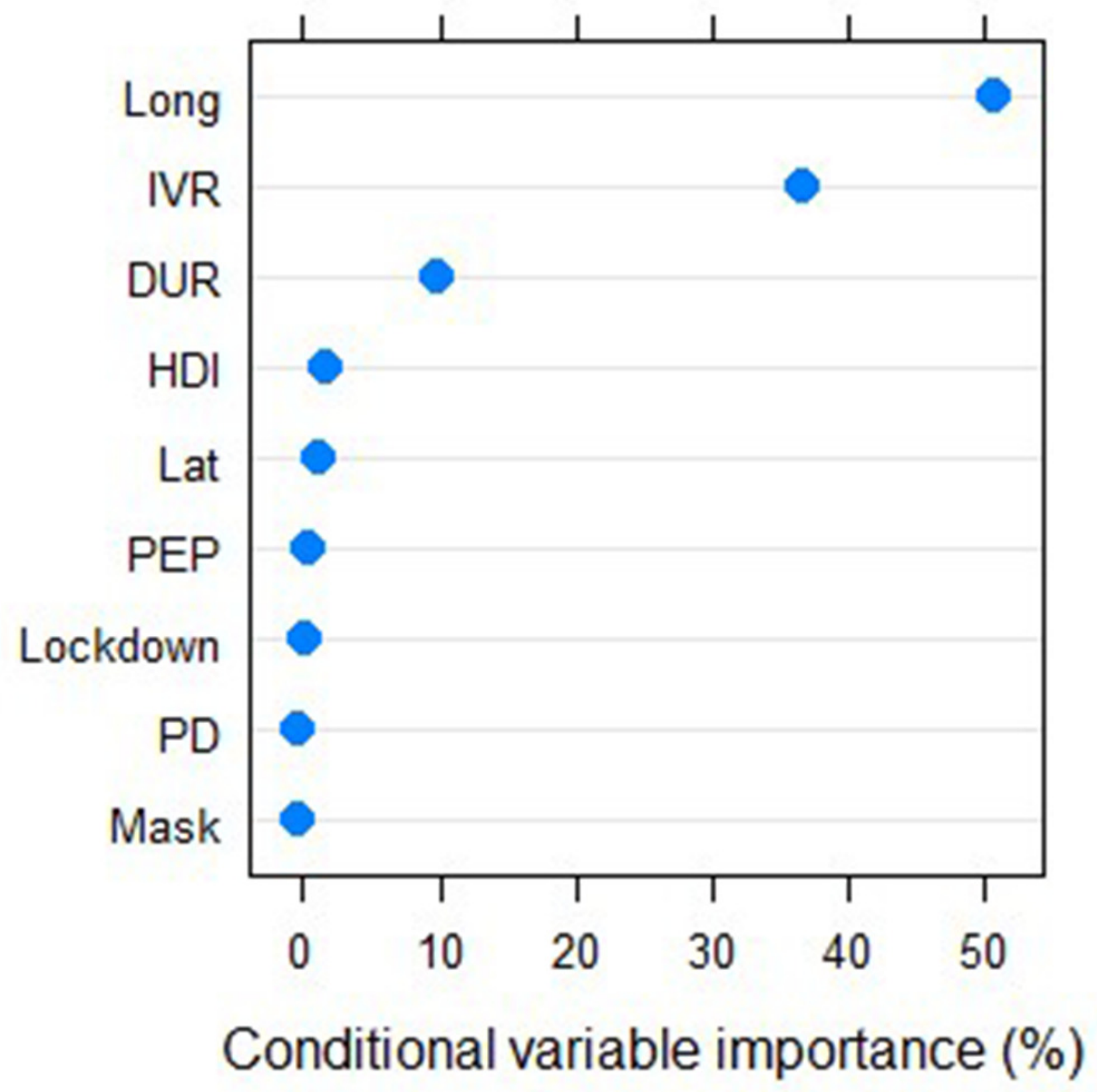




\section{Figure 5}

Conditional variables importance ranking to predict COVID-19 Case Fatality Ratio.

Unbiased conditional variables importance ranking (\%) to predict COVID-19 Case Fatality Ratio using the package "party" and the non-parametric random forest function "cforest" in the software $R$; IVR = influenza vaccination rate, Long = centroid longitude $\left({ }^{\circ}\right)$, Lat $=$ centroid latitude $\left({ }^{\circ}\right)$, DUR $=$ degree of urbanization in 2020, $\mathrm{HDI}=$ Human Development Index in 2018, PEP = percent of elder people in 2019, PD = population density in 2018, mask $=$ the requirement degree of using masks in public (with three degrees: none, parts of country, full country), lockdown = lockdown degree ( with three levels: no lockdown, partial lockdown, nationwide lockdown) of each country, at worldwide level (39 countries studied). 


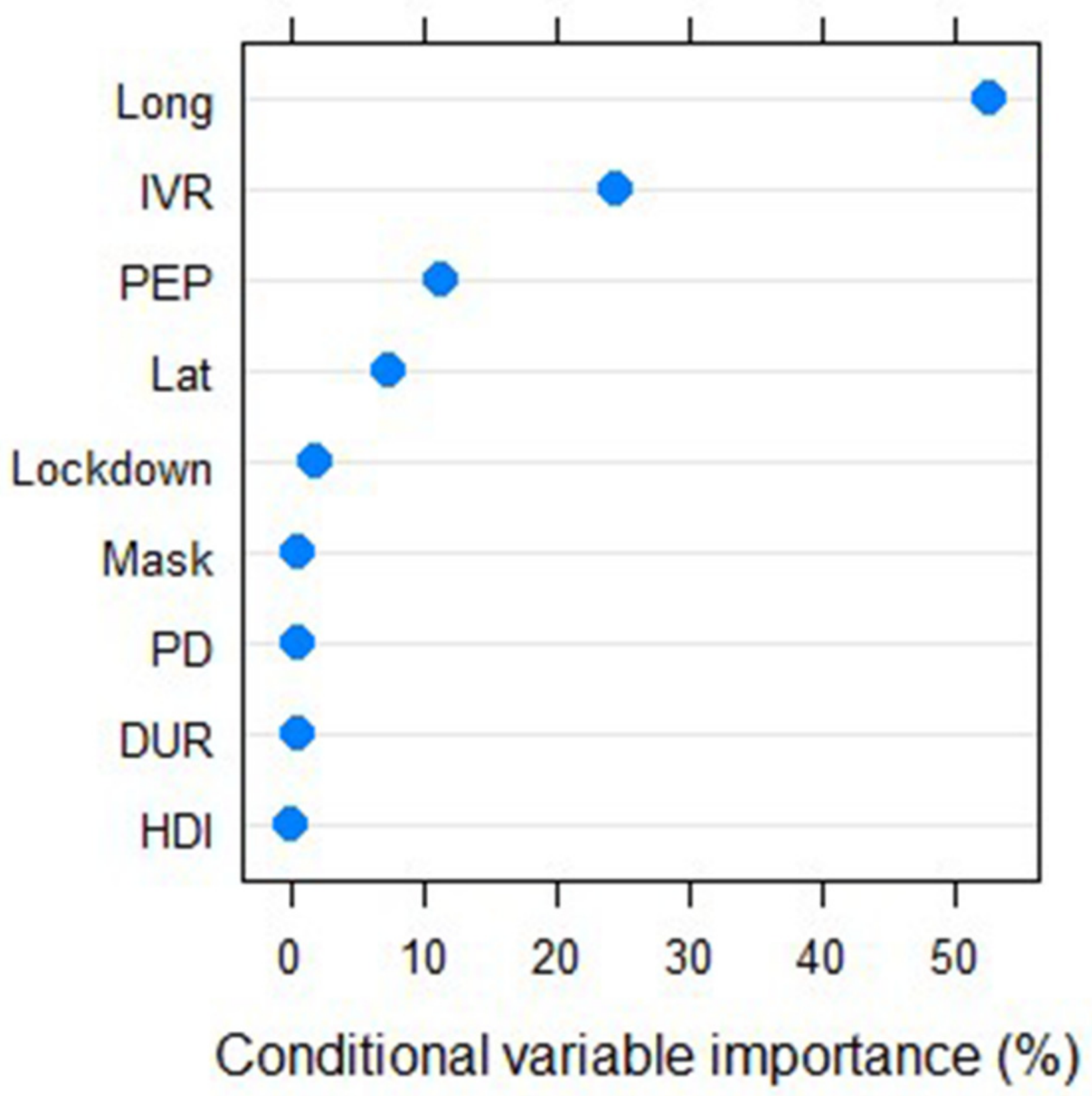




\section{Table $\mathbf{1}$ (on next page)}

Raw data (part 1).

Countries with their influenza vaccination rate (IVR) (\%) of people aged 65 and older in 2019 or latest available, COVID-19 deaths per million inhabitants (DPMI), COVID-19 Case Fatality Ratio (CFR) based on documented COVID-19 cases per million inhabitants (CPMI) in 2020, COVID-19 tests per million inhabitants. 


\begin{tabular}{|c|c|c|c|c|c|c|c|}
\hline Country & $\begin{array}{c}\text { IVR* } \\
(\%)\end{array}$ & $\begin{array}{c}\text { Year of } \\
\text { IVR }\end{array}$ & $\begin{array}{c}\text { DPMI }^{+} \\
(\mathbf{N} \text { per } \mathbf{M})\end{array}$ & $\begin{array}{c}\mathrm{CPMI}^{+} \\
(\mathrm{N} \text { per } \mathrm{M})\end{array}$ & $\mathrm{CFR}^{+}$ & $\begin{array}{l}\text { COVID- } \\
19 \text { tests }^{+}\end{array}$ & Continent \\
\hline Australia & 73.0 & $2018 / 2019$ & 6 & 547 & 0.011 & 151,037 & $\begin{array}{c}\text { Australia } \\
\text { and } \\
\text { Ozeanien }\end{array}$ \\
\hline Belgium & 59.1 & 2019 & 847 & 5,624 & 0.151 & 130,601 & Europe \\
\hline Brazil & 71.8 & $2018 / 2019$ & 402 & 11,078 & 0.036 & 23,094 & America \\
\hline Canada & 59.0 & 2019 & 235 & 3,006 & 0.078 & 98,442 & America \\
\hline Chile & 68.3 & 2019 & 472 & 17,964 & 0.026 & 78,678 & America \\
\hline China & 7.0 & $2018 / 2019$ & 3 & 58 & 0.052 & 62,814 & Asia \\
\hline Croatia & 23.0 & 2017 & 31 & 1,168 & 0.027 & 26,932 & Europe \\
\hline $\begin{array}{c}\text { Czech } \\
\text { Republic }\end{array}$ & 21.5 & 2019 & 34 & 1,413 & 0.024 & 61,332 & Europe \\
\hline Denmark & 52.0 & 2019 & 106 & 2,319 & 0.046 & 243,677 & Europe \\
\hline Estonia & 10.2 & 2019 & 52 & 1,532 & 0.034 & 87,692 & Europe \\
\hline Finland & 49.5 & 2019 & 59 & 1,333 & 0.044 & 59,654 & Europe \\
\hline France & 51.0 & 2019 & 462 & 2,765 & 0.167 & 45,683 & Europe \\
\hline Germany & 34.8 & 2019 & 110 & 2,460 & 0.045 & 88,528 & Europe \\
\hline Greece & 56.2 & 2019 & 19 & 400 & 0.048 & 42,244 & Europe \\
\hline Hungary & 24.1 & 2019 & 62 & 458 & 0.135 & 33,116 & Europe \\
\hline Ireland & 68.5 & 2019 & 357 & 5,235 & 0.068 & 121,496 & Europe \\
\hline Israel & 59.8 & 2019 & 49 & 6,577 & 0.007 & 173,662 & Europe \\
\hline Italy & 53.1 & 2019 & 581 & 4,067 & 0.143 & 107,848 & Europe \\
\hline Japan & 48.0 & 2019 & 8 & 221 & 0.036 & 5,516 & Asia \\
\hline Latvia & 11.7 & 2019 & 16 & 640 & 0.025 & 100,009 & Europe \\
\hline Lithuania & 14.8 & 2019 & 29 & 736 & 0.039 & 182,847 & Europe \\
\hline Luxembourg & 39.8 & 2019 & 179 & 9,665 & 0.019 & 618,326 & Europe \\
\hline Mexico & 82.3 & $2018 / 2019$ & 331 & 2,932 & 0.113 & 6,946 & America \\
\hline Netherlands & 62.7 & 2019 & 358 & 3,077 & 0.116 & 49,709 & Europe \\
\hline New Zealand & 62.0 & 2019 & 4 & 311 & 0.013 & 90,746 & $\begin{array}{c}\text { Australia } \\
\text { and } \\
\text { Ozeanien }\end{array}$ \\
\hline Norway & 38.2 & 2019 & 47 & 1,677 & 0.028 & 77,531 & Europe \\
\hline Portugal & 60.8 & 2019 & 168 & 4,900 & 0.034 & 149,941 & Europe \\
\hline Romania & 16.1 & 2017 & 112 & 2,272 & 0.049 & 56,571 & Europe \\
\hline Singapore** & 14.0 & $2016 / 2017$ & 5 & 8,523 & 0.001 & 199,896 & Asia \\
\hline $\begin{array}{c}\text { Slovak } \\
\text { Republic } \\
\end{array}$ & 12.5 & 2019 & 5 & 392 & 0.013 & 46,285 & Europe \\
\hline Slovenia & 12.9 & 2019 & 55 & 994 & 0.055 & 61,108 & Europa \\
\hline South Korea & 85.1 & 2019 & 6 & 275 & 0.022 & 29,619 & Asia \\
\hline Spain & 54.9 & 2019 & 608 & 6,833 & 0.089 & 135,188 & Europe \\
\hline Sweden & 52.2 & 2019 & 562 & 7,819 & 0.072 & 74,353 & Europe \\
\hline Thailand & 12.0 & $2018 / 2019$ & 0.8 & 47 & 0.017 & 9,817 & Asia \\
\hline Turkey & 7.0 & 2019 & 66 & 2,668 & 0.025 & 53,707 & Europe \\
\hline
\end{tabular}




\begin{tabular}{cccccccc}
\hline $\begin{array}{c}\text { United } \\
\text { Kingdom }\end{array}$ & 72.0 & 2019 & 673 & 4,398 & 0.153 & 214,532 & Europe \\
\hline United States & 68.7 & 2019 & 450 & 12,929 & 0.035 & 159,672 & America \\
\hline Vietnam*** & 12.0 & 2017 & 0 & 4 & 0.000 & 2,824 & Asia \\
\hline
\end{tabular}

2 Note: *Taken from https://data.oecd.org/healthcare/influenza-vaccination-rates.htm,

3 https://oecdcode.org/disclaimers/israel.html and https://www.statista.com/chart/16575/global-flu-immunization-

4 rates-vary/ on July $25,2020,{ }^{*}$ from https://www.todayonline.com/commentary/why-singapores-adult-

5 vaccination-rate-so-low. ${ }^{* * *}$ from Nguyen et al. (2020), ${ }^{+}$from https://www.worldometers.info/coronavirus/

6 on July $25,2020$. 


\section{Table 2 (on next page)}

Raw data (part 2).

Countries with their centroid coordinates (longitude (Long) and latitude (Lat)), Degree of urbanization in 2020, Human Development Index (HDI) in 2018, Percent elder people in 2019 and Population density in 2018. 
1

\begin{tabular}{|c|c|c|c|c|c|c|}
\hline Country & $\begin{array}{c}\text { Long } \\
\left({ }^{\circ}\right)\end{array}$ & $\begin{array}{c}\text { Lat } \\
\left({ }^{\circ}\right)\end{array}$ & $\begin{array}{c}\text { Degree of } \\
\text { urbanization } \\
(\mathbf{2 0 2 0})^{*}\end{array}$ & $\begin{array}{c}\text { HDI } \\
(2018)^{* * *}\end{array}$ & $\begin{array}{c}\begin{array}{c}\text { Percent } \\
\text { elder } \\
\text { people (\%) } \\
(\mathbf{2 0 1 9}) * * *\end{array} \\
\end{array}$ & $\begin{array}{c}\text { Population density } \\
\text { (people per } \mathbf{k m}^{2} \text { of } \\
\text { land area) } \\
(2018)^{* * * *}\end{array}$ \\
\hline Australia & 134.5 & -25.7 & 86.2 & 0.938 & 15.92 & 3.2 \\
\hline Belgium & 4.6 & 50.6 & 98.1 & 0.919 & 19.01 & 377.4 \\
\hline Brazil & -53.1 & -10.8 & 87.1 & 0.761 & 9.25 & 25.1 \\
\hline Canada & -98.3 & 61.4 & 81.6 & 0.922 & 17.65 & 4.1 \\
\hline Chile & -71.4 & -37.7 & 87.7 & 0.847 & 11.88 & 25.2 \\
\hline China & 103.8 & 36.6 & 61.4 & 0.758 & 11.47 & 148.3 \\
\hline Croatia & 16.4 & 45.1 & 57.6 & 0.837 & 20.86 & 73.0 \\
\hline Czech Republic & 15.3 & 49.7 & 74.1 & 0.891 & 19.80 & 137.7 \\
\hline Denmark & 10.0 & 56.0 & 88.1 & 0.930 & 19.97 & 138.0 \\
\hline Estonia & 25.5 & 58.7 & 69.2 & 0.882 & 19.99 & 30.4 \\
\hline Finland & 26.3 & 64.5 & 85.5 & 0.925 & 22.14 & 18.1 \\
\hline France & 2.5 & 46.2 & 81.0 & 0.891 & 20.39 & 122.3 \\
\hline Germany & 15.3 & 49.7 & 77.5 & 0.939 & 21.56 & 237.3 \\
\hline Greece & 23.0 & 39.1 & 79.7 & 0.872 & 21.94 & 83.3 \\
\hline Hungary & 19.4 & 47.2 & 71.9 & 0.845 & 19.69 & 108.0 \\
\hline Ireland & -8.1 & 53.2 & 63.7 & 0.942 & 14.22 & 70.7 \\
\hline Israel & 35.0 & 31.5 & 92.6 & 0.906 & 12.21 & 410.5 \\
\hline Italy & 12.1 & 42.8 & 71.0 & 0.883 & 23.01 & 205.4 \\
\hline Japan & 138.0 & 37.6 & 91.8 & 0.915 & 28.00 & 347.1 \\
\hline Latvia & 24.9 & 56.9 & 68.3 & 0.854 & 20.34 & 31.0 \\
\hline Lithuania & 23.9 & 55.3 & 68.0 & 0.869 & 20.16 & 44.7 \\
\hline Luxembourg & 6.1 & 49.8 & 91.5 & 0.909 & 14.27 & 250.2 \\
\hline Mexico & -102.5 & 23.9 & 80.7 & 0.767 & 7.42 & 64.9 \\
\hline Netherlands & 5.3 & 52.1 & 92.2 & 0.933 & 19.61 & 511.5 \\
\hline New Zealand & 171.5 & -41.8 & 86.7 & 0.921 & 15.99 & 18.4 \\
\hline Norway & 15.3 & 68.8 & 83.0 & 0.954 & 17.27 & 14.5 \\
\hline Portugal & -8.5 & 39.6 & 66.3 & 0.850 & 22.36 & 112.3 \\
\hline Romania & 25.0 & 45.9 & 56.4 & 0.816 & 18.79 & 84.6 \\
\hline Singapore & 103.8 & 1.4 & 100.0 & 0.935 & 12.39 & 7953.0 \\
\hline Slovak Republic & 19.5 & 48.7 & 53.8 & 0.857 & 16.17 & 113.3 \\
\hline Slovenia & 14.8 & 46.1 & 55.1 & 0.902 & 20.19 & 103.0 \\
\hline South Korea & 127.8 & 36.4 & 81.4 & 0.906 & 15.06 & 529.4 \\
\hline Spain & -3.6 & 40.2 & 80.8 & 0.893 & 19.65 & 93.7 \\
\hline Sweden & 16.7 & 62.8 & 88.0 & 0.937 & 20.20 & 25.0 \\
\hline Thailand & 101.0 & 15.1 & 51.4 & 0.765 & 12.41 & 135.9 \\
\hline Turkey & 35.2 & 39.1 & 76.1 & 0.806 & 8.73 & 107.0 \\
\hline United Kingdom & -2.9 & 54.1 & 83.9 & 0.920 & 18.51 & 274.7 \\
\hline
\end{tabular}




\begin{tabular}{ccccccc}
\hline United States & -112.5 & 45.7 & 82.7 & 0.920 & 16.21 & 35.7 \\
\hline Vietnam & 106.3 & 16.6 & 37.3 & 0.693 & 7.55 & 308.1 \\
\hline
\end{tabular}

2 Note: ${ }^{*}$ https://www.cia.gov/library/publications/the-world-factbook/fields/349.html, **

3 http://hdr.undp.org/en/composite/HDI, ${ }^{* *}$ https://data.worldbank.org/indicator/SP.POP.65UP.TO.ZS?name desc=false, ${ }^{* * * *}$

4 https://data.worldbank.org/indicator/EN.POP.DNST, all retrieved on July 13, 2020. 


\section{Table 3 (on next page)}

Raw data (part 3).

Countries with some Covid-19 measures (degree of mask requirements in public, lockdown degree and lockdown beginning). 


\begin{tabular}{|c|c|c|c|c|}
\hline Country & $\begin{array}{l}\text { Degree of } \\
\text { mask } \\
\text { requirement* }\end{array}$ & $\begin{array}{l}\text { Lockdown } \\
\text { degree }\end{array}$ & $\begin{array}{l}\text { Lockdown } \\
\text { beginning }\end{array}$ & $\begin{array}{l}\text { Sources about lockdown } \\
\text { (retrieved on Aug 13, 2020) }\end{array}$ \\
\hline Australia & $\begin{array}{l}\text { Parts of } \\
\text { Country }\end{array}$ & Lockdown & $3 / 23 / 20$ & $\begin{array}{l}\text { https://www.straitstimes.com/asia/australianz/australia-starts-lockdown- } \\
\text { measures-as-coronavirus-cases-jump }\end{array}$ \\
\hline Belgium & Full Country & Lockdown & $3 / 17 / 20$ & $\begin{array}{l}\text { https://www.euractiv.com/section/coronavirus/news/belgium-enters- } \\
\text { lockdown-over-coronavirus-crisis-until-5-april// }\end{array}$ \\
\hline Brazil & $\begin{array}{l}\text { Parts of } \\
\text { Country }\end{array}$ & Lockdown & $5 / 5 / 20$ & $\begin{array}{l}\text { https://www.reuters.com/article/us-health-coronavirus-brazil- } \\
\text { lockdown/major-brazilian-cities-set-lockdowns-as-virus-spreads- } \\
\text { idUSKBN22H2V3 }\end{array}$ \\
\hline Canada & $\begin{array}{l}\text { Parts of } \\
\text { Country }\end{array}$ & $\begin{array}{c}\text { Partial } \\
\text { lockdown }\end{array}$ & $3 / 17 / 20$ & $\begin{array}{l}\text { https://www.manitoulin.ca/updated-canada-goes-on-covid-19- } \\
\text { lockdown/ }\end{array}$ \\
\hline Chile & Full Country & $\begin{array}{c}\text { Partial } \\
\text { lockdown }\end{array}$ & $3 / 25 / 20$ & $\begin{array}{l}\text { https://www.gob.cl/noticias/ministerio-de-salud-anuncia-cuarentena- } \\
\text { total-para-siete-comunas-de-la-region-metropolitana/ }\end{array}$ \\
\hline China & $\begin{array}{c}\text { None, but } \\
\text { voluntary } \\
\text { Universal } \\
\text { Mask Usage }\end{array}$ & Lockdown & $1 / 23 / 20$ & https://www.who.int/bulletin/volumes/98/7/20-254045/en/ \\
\hline Croatia & Full Country & Lockdown & $3 / 18 / 20$ & $\begin{array}{l}\text { https://www.telegram.hr/zivot/koronavirus-krizni-stozer-danas-ce- } \\
\text { objaviti-sto-se-sve-zatvara-u-hrvatskoj/; } \\
\text { https://m.vecernji.hr/vijesti/oxford-hrvatska-ima-najstroze-mjere-u- } \\
\text { europi-iza-su-samo-srbija-i-sirija-1389281 }\end{array}$ \\
\hline $\begin{array}{l}\text { Czech } \\
\text { Republic }\end{array}$ & Full Country & Lockdown & $3 / 16 / 20$ & $\begin{array}{l}\text { https://archiv.radio.cz/en/section/breaking/czech-republic-severely- } \\
\text { limits-freedom-of-movement-in-order-to-slow-down-coronavirus- } \\
\text { spread }\end{array}$ \\
\hline Denmark & None & Lockdown & $3 / 13 / 20$ & $\begin{array}{l}\text { https://nyheder.tv2.dk/samfund/2020-03-11-danmark-lukker-ned-her- } \\
\text { er-regeringens-nye-tiltag }\end{array}$ \\
\hline Estonia & $\begin{array}{l}\text { None, but } \\
\text { Recommends } \\
\text { Masks } \\
\end{array}$ & $\begin{array}{l}\text { No } \\
\text { lockdown }\end{array}$ & & $\begin{array}{l}\text { https://www.euronews.com/2020/05/13/coronavirus-lockdown-latvia- } \\
\text { lithuania-and-estonia-re-open-borders-to-each-other }\end{array}$ \\
\hline Finland & $\begin{array}{l}\text { None, but } \\
\text { Recommends } \\
\text { Masks }\end{array}$ & $\begin{array}{l}\text { Partial } \\
\text { lockdown }\end{array}$ & $3 / 28 / 20$ & $\begin{array}{l}\text { https://newseu.cgtn.com/news/2020-04-16/Finland-to-lift-coronavirus- } \\
\text { lockdown-in-region-around-capital--PIiAE4MM36/index.html }\end{array}$ \\
\hline France & Full Country & Lockdown & $3 / 17 / 20$ & $\begin{array}{l}\text { https://www.leparisien.fr/societe/coronavirus-etat-d-urgence-aux-etats- } \\
\text { unis-800-nouveaux-cas-en-france-79-morts-au-total-suivez-notre- } \\
\text { direct-14-03-2020-8279826.php }\end{array}$ \\
\hline Germany & Full Country & Lockdown & $3 / 23 / 20$ & $\begin{array}{l}\text { https://www.welt.de/politik/deutschland/article206725829/Coronavirus- } \\
\text { Deutschland-Kontaktverbote-zu-mehr-als-zwei-Personen-Friseure- } \\
\text { zu.html }\end{array}$ \\
\hline Greece & Full Country & Lockdown & $3 / 23 / 20$ & $\begin{array}{l}\text { https://www.in.gr/2020/04/23/politics/se-ekseliksi-enimerosi-tou- } \\
\text { kyvernitikou-ekprosopou-steliou-petsa-2/ }\end{array}$ \\
\hline Hungary & $\begin{array}{l}\text { Parts of } \\
\text { Country }\end{array}$ & Lockdown & $3 / 28 / 20$ & $\begin{array}{l}\text { https://www.theguardian.com/world/2020/mar/30/hungary-jail-for- } \\
\text { coronavirus-misinformation-viktor-orban }\end{array}$ \\
\hline Ireland & $\begin{array}{l}\text { No, but } \\
\text { Recommends } \\
\text { Masks } \\
\end{array}$ & Lockdown & $3 / 12 / 20$ & $\begin{array}{l}\text { https://www.irishtimes.com/news/health/coronavirus-schools-colleges- } \\
\text { and-childcare-facilities-in-ireland-to-shut-1.4200977 }\end{array}$ \\
\hline Israel & Full Country & Lockdown & $4 / 1 / 20$ & $\begin{array}{l}\text { https://www.haaretz.com/israel-news/coronavirus-israeli-health- } \\
\text { minister-netanyahu-mossad-chief-quarantine-1.8720108; } \\
\text { https://www.timesofisrael.com/israelis-will-be-required-to-wear-face- } \\
\text { masks-outdoors-under-new-order/ }\end{array}$ \\
\hline Italy & Full Country & Lockdown & $2 / 25 / 20$ & $\begin{array}{l}\text { https://metro.co.uk/2020/02/25/towns-italy-lockdown-coronavirus- } \\
12298246 /\end{array}$ \\
\hline Japan & $\begin{array}{c}\text { No, but } \\
\text { Universal } \\
\text { Mask Usage }\end{array}$ & $\begin{array}{l}\text { No } \\
\text { lockdown }\end{array}$ & & $\begin{array}{l}\text { https://asia.nikkei.com/Spotlight/Coronavirus/Japan-quietly-reopens-as- } \\
\text { much-of-world-locks-down }\end{array}$ \\
\hline Latvia & Full Country & $\begin{array}{c}\text { No } \\
\text { lockdown }\end{array}$ & & $\begin{array}{l}\text { https://www.euronews.com/2020/05/13/coronavirus-lockdown-latvia- } \\
\text { lithuania-and-estonia-re-open-borders-to-each-other }\end{array}$ \\
\hline Lithuania & Full Country & $\begin{array}{c}\text { No } \\
\text { lockdown }\end{array}$ & & $\begin{array}{l}\text { https://www.euronews.com/2020/05/13/coronavirus-lockdown-latvia- } \\
\text { lithuania-and-estonia-re-open-borders-to-each-other }\end{array}$ \\
\hline Luxembourg & Full Country & Lockdown & $4 / 15 / 20$ & $\begin{array}{l}\text { https://www.tageblatt.lu/headlines/pressekonferenz-nach-dem- } \\
\text { regierungsrat-kommt-das-ende-des-lockdowns/ }\end{array}$ \\
\hline
\end{tabular}




\begin{tabular}{|c|c|c|c|c|}
\hline Mexico & Full Country & Lockdown & $3 / 23 / 20$ & $\begin{array}{l}\text { https://www.eluniversal.com.mx/english/mexico-city-closes-museums- } \\
\text { bars-nightclubs-and-movie-theaters-bid-halt-coronavirus-spread }\end{array}$ \\
\hline Netherlands & Full Country & Lockdown & $3 / 12 / 20$ & $\begin{array}{l}\text { Maarten Keulemans ( } 12 \text { March 2020). "Are we doing enough? RIVM } \\
\text { boss Van Dissel: 'As soon as something indicates infection in the } \\
\text { family: isolation"'. de Volkskrant (in Dutch). Retrieved } 13 \text { March } 2020 .\end{array}$ \\
\hline $\begin{array}{c}\text { New } \\
\text { Zealand }\end{array}$ & None & Lockdown & $3 / 26 / 20$ & $\begin{array}{l}\text { https://www.newstalkzb.co.nz/news/national/coronavirus-covid-19- } \\
\text { state-of-emergency-declared-in-new-zealand-50-new-cases-confirmed/ }\end{array}$ \\
\hline Norway & None & Lockdown & $3 / 12 / 20$ & $\begin{array}{l}\text { https://www.nrk.no/norge/alle-utdanningsinstitusjoner-stenges-_-flere- } \\
\text { arrangementer-og-virksomheter-far-forbud-1.14940952 }\end{array}$ \\
\hline Portugal & Full Country & Lockdown & $3 / 19 / 20$ & http://www.presidencia.pt $/$ idc $=22 \&$ idi $=176060$ \\
\hline Romania & Full Country & Lockdown & $3 / 25 / 20$ & http://www.ms.ro/2020/03/25/buletin-informativ-25-03-2020/ \\
\hline Singapore & Full Country & Lockdown & $4 / 7 / 20$ & $\begin{array}{l}\text { https://www.channelnewsasia.com/news/business/suntec-city-waives- } \\
\text { april-rent-for-tenants-covid-19-12614802 }\end{array}$ \\
\hline $\begin{array}{c}\text { Slovak } \\
\text { Republic }\end{array}$ & Full Country & Lockdown & $3 / 12 / 20$ & $\begin{array}{l}\text { https://spectator.sme.sk/c/22356193/emergency-situation-applies-from- } \\
\text { thursday-morning.html?ref=njctse }\end{array}$ \\
\hline Slovenia & Full Country & Lockdown & $3 / 13 / 20$ & $\begin{array}{l}\text { https://www.rtvslo.si/zdravje/novi-koronavirus/katalonija-zeli- } \\
\text { razglasiti-karanteno-za-celotno-pokrajino/517068 }\end{array}$ \\
\hline South Korea & $\begin{array}{c}\text { None, but } \\
\text { voluntary } \\
\text { Universal } \\
\text { Mask Usage }\end{array}$ & $\begin{array}{l}\text { No } \\
\text { lockdown }\end{array}$ & & $\begin{array}{l}\text { https://www.sciencemag.org/news/2020/03/coronavirus-cases-have- } \\
\text { dropped-sharply-south-korea-whats-secret-its-success }\end{array}$ \\
\hline Spain & Full Country & Lockdown & $3 / 14 / 20$ & $\begin{array}{l}\text { https://administracion.gob.es/pag_Home/atencionCiudadana/Estado-de- } \\
\text { alarma-crisis-sanitaria.html\#.Xn3xj0dKjIU }\end{array}$ \\
\hline Sweden & None & $\begin{array}{c}\text { No } \\
\text { lockdown }\end{array}$ & & $\begin{array}{l}\text { Sayers, Freddy (17 April 2020). Swedish expert: why lockdowns are } \\
\text { the wrong policy - The Post. UnHerd. }\end{array}$ \\
\hline Thailand & Full Country & Lockdown & $4 / 3 / 20$ & $\begin{array}{l}\text { https://www.bangkokpost.com/thailand/general/1891910/curfew-starts- } \\
\text { today }\end{array}$ \\
\hline Turkey & Full Country & $\begin{array}{c}\text { Partial } \\
\text { lockdown }\end{array}$ & $3 / 21 / 20$ & $\begin{array}{l}\text { ttps://www.bbc.com/news/world-europe-52831017; } \\
\text { https://www.aa.com.tr/tr/koronavirus/cumhurbaskanligi-sozcusu-kalin- } \\
\text { ilk-orta-ve-liseler-1-hafta-universiteler-3-hafta-tatil-edilecek/1763918 }\end{array}$ \\
\hline $\begin{array}{c}\text { United } \\
\text { Kingdom }\end{array}$ & Full Country & Lockdown & $3 / 23 / 20$ & $\begin{array}{l}\text { https://www.thesun.co.uk/news/11304061/uk-coronavirus-lockdown- } \\
\text { month-lasted-start-end/ }\end{array}$ \\
\hline $\begin{array}{l}\text { United } \\
\text { States }\end{array}$ & $\begin{array}{l}\text { Parts of } \\
\text { Country }\end{array}$ & Lockdown & $3 / 19 / 20$ & $\begin{array}{l}\text { https://www.wsj.com/articles/china-reports-no-new-domestic- } \\
\text { coronavirus-infections-for-the-first-time-since-outbreak-started- } \\
11584611233\end{array}$ \\
\hline Vietnam & Full Country & Lockdown & $4 / 1 / 20$ & $\begin{array}{l}\text { https://e.vnexpress.net/news/news/covid-19-lockdown-hanoi-hospital- } \\
\text { lacks-food-necessities-for-3-500-inmates-4077071.html }\end{array}$ \\
\hline
\end{tabular}

1

2 Note: * https://masks4all.co/what-countries-require-masks-in-public/(retrieved on Aug 13, 2020) 


\section{Table 4 (on next page)}

Spearman correlations $\left(r_{s}\right)$ of COVID-19 deaths per million inhabitants (DP) with nine predictor variables.

Spearman correlations $\left(r_{s}\right)$ of COVID-19 deaths per million inhabitants (DPMI) with the variables (var): IVR = influenza vaccination rate (IVR, \%) of people aged 65 and older in 2019 or latest data available, Long and Lat $=$ Longitude and Latitude of the country centroid $\left({ }^{\circ}\right)$, DUR $=$ Degree of urbanization in 2020, $\mathrm{HDI}=$ Human Development Index in 2018, PEP = Percent elder people in 2019, PD = Population density in 2018, Mask = the requirement degree of using masks in public (with three degrees: none, parts of country, full country), Lockdown = lockdown degree (with three levels: no lockdown, partial lockdown, nationwide lockdown) and their $p$ values based on 26 countries in Europe (Tables $1-3$ ). 
1

\begin{tabular}{ccc}
\hline var & $\boldsymbol{r}_{\boldsymbol{s}}$ (DPMI x var) & $\boldsymbol{p}$ value \\
\hline Long & $\mathbf{- 0 . 6 5}$ & $\mathbf{0 . 0 0 0 3}$ \\
\hline IVR & $\mathbf{0 . 6 2}$ & $\mathbf{0 . 0 0 0 8}$ \\
\hline DUR & 0.43 & 0.0273 \\
\hline PD & 0.41 & 0.0375 \\
\hline HDI & 0.38 & 0.0533 \\
\hline Lockdown & 0.25 & 0.2146 \\
\hline PEP & -0.07 & 0.7387 \\
\hline Lat (abs) & -0.02 & 0.9313 \\
\hline Mask & 0 & 0.9949
\end{tabular}

2 Note: bold $=$ statistically significant after Bonferroni correction $(\alpha=0.0019)$.

3 


\section{Table 5 (on next page)}

Spearman correlations $\left(r_{s}\right)$ of COVID-19 deaths per million inhabitants (DP) and COVID-19 Case Fatality Ratio (CFR) with nine predictor variables.

Spearman correlations $\left(r_{s}\right)$ of COVID-19 deaths per million inhabitants (DPMI) and COVID-19 Case Fatality Ratio (CFR) with the variables: IVR = influenza vaccination rate (\%) of people aged 65 and older in 2019 or latest available, Long = Longitude of the centroid of the country $\left({ }^{\circ}\right)$, Latitude of the centroid of the country $\left({ }^{\circ}\right)$, DUR $=$ Degree of urbanization in 2020, $\mathrm{HDI}=$ Human Development Index in 2018, PEP = Percent elder persons in 2019, PD = Population density in 2018, Mask = the requirement degree of using masks in public (with three degrees: none, parts of country, full country), Lockdown = lockdown degree (with three levels: no lockdown, partial lockdown, nationwide lockdown), based on 39 countries worldwide (Tables 1 - 3). 


\begin{tabular}{|c|c|c|}
\hline$r_{s}$ & DPMI & CFR \\
\hline Long & -0.81 & -0.56 \\
\hline IVR & 0.49 & 0.25 \\
\hline DUR & 0.32 & 0.39 \\
\hline Lat (abs) & 0.32 & 0.03 \\
\hline HDI & 0.20 & 0.10 \\
\hline PEP & 0.15 & 0.38 \\
\hline Mask & 0.14 & -0.01 \\
\hline Lockdown & 0.08 & 0.09 \\
\hline PD & -0.07 & -0.01 \\
\hline \multicolumn{3}{|l|}{$p$ values } \\
\hline Long & 0 & 0.0002 \\
\hline IVR & 0.0016 & 0.1275 \\
\hline DUR & 0.0436 & 0.8698 \\
\hline Lat (abs) & 0.0451 & 0.0155 \\
\hline HDI & 0.2167 & 0.5529 \\
\hline PEP & 0.3523 & 0.0174 \\
\hline Mask & 0.3819 & 0.9436 \\
\hline Lockdown & 0.6448 & 0.5980 \\
\hline PD & 0.6713 & 0.9347 \\
\hline
\end{tabular}

14 Note: bold = statistically significant after Bonferroni correction $(\alpha=0.0019)$.

15 